\title{
Insecticide-treated durable wall lining for malaria control: multicentre studies from Africa and South-East Asia
}

\author{
Louisa A Messenger ${ }^{1 *}$, Abrahan Matias Arnez ${ }^{2}$, JB Stiles-Ocran ${ }^{3}$, Mamadou B Coulibaly ${ }^{4}$, Marie-Louise Larsen ${ }^{5}$, \\ Nathan Miller ${ }^{6}$, Adedapo O Adeogun ${ }^{7}$, CEG Mulder ${ }^{8}$, Hoan Le $^{9}$, Immo Kleinschmidt', Mark Rowland ${ }^{1}$
}

From Challenges in malaria research

Basel, Switzerland. 10-12 October 2012

\section{Background}

Indoor residual spraying (IRS) is a primary method of malaria vector control but its potential impact is constrained by several inherent limitations: spraying must be repeated when insecticide residues decay, householders may object to the annual imposition and campaign costs are recurrent. Durable wall lining (DL) can be considered a novel form of long-lasting IRS, which gradually releases insecticide over a period of three to four years when used to cover interior house walls. DL is designed to overcome the logistical constraints associated with repeated rounds of spraying whilst retaining the most attractive feature of IRS, the protection of all members of the community [1-3]. To establish DL as a viable substitute it must demonstrate equivalent or superior levels of bioefficacy, acceptability, durability and logistical feasibility to currently available products.

\section{Materials and methods}

To identify a desirable material to develop into a durable wall lining, a one year preliminary trial was conducted among rural and urban households in Angola and Nigeria $(\mathrm{n}=258)$ comparing three deltamethrin-treated prototype materials (polyethylene shade cloth, laminated polyethylene sheeting and mosquito wall netting) [4]. The most popular lining material (shade cloth polyethylene, henceforth DL) was then evaluated in comparison with conventional IRS during a one year multicentre trial conducted in rural households in malaria endemic Equatorial Guinea, Ghana, Mali, South Africa and Vietnam $(n=220)$.

${ }^{1}$ Department of Disease Control, London School of Hygiene and Tropical Medicine, London, UK

Full list of author information is available at the end of the article

\section{Results}

During the preliminary trial a dichotomy between rural and urban participants emerged. Rural households favoured wall adornments and accepted wall linings because of their perceived decorative value and entomological efficacy, whereas urban households preferred minimal wall decoration and objected to the materials aesthetics and installation feasibility. Of the prototype lining materials assessed, polyethylene shade cloth DL was the most popular because of its ease of installation, aesthetics and resemblance to locally available materials. During the multicentre field trial, DL demonstrated consistently higher levels of bioefficacy compared to IRS, with no significant loss of bioactivity after 12 months. Field samples of DL retained on average $78 \%$ of their original insecticide content after one year. The majority of households reported reductions in mosquito density (93\%) and biting (82\%), but no adverse changes to their indoor environment (83\%). When offered a choice of vector control product at the end of trial, the majority of participants chose DL regardless of the earlier household allocation.

\section{Conclusions}

These two trials represent the largest field evaluation of DL to date [4]. The high level of acceptability among rural inhabitants identifies these communities as the ideal target consumer group for DL. DL remained fully efficacious against mosquito vectors, demonstrated minimal loss of insecticide content over 12 months of field use and was unequivocally more popular than IRS and other long-lasting vector control products. Together these results demonstrate that DL has the potential to overcome many of the operational challenges associated with IRS and may 
represent a viable long-lasting alternative, a scenario not dissimilar to the advantages and superiority shown by long-lasting insecticidal nets when introduced in place of conventional insecticide-treated nets.

\section{Author details}

'Department of Disease Control, London School of Hygiene and Tropical Medicine, London, UK. ${ }^{2}$ Medical Care Development International (MCDI), Malabo, Equatorial Guinea. ${ }^{3}$ Entomology Research Unit, Malaria Control Centre, AngloGold Ashanti Ltd., Obuasi, Ghana. ${ }^{4}$ Vector Genomics and Proteomics, Malaria Research and Training Centre (MRTC), University of Sciences, Techniques and Technologies, Bamako, Mali. ${ }^{5}$ Technical Institute of Denmark (DTU), Lyngby Denmark. ${ }^{6}$ The MENTOR Initiative, Huambo, Angola. ${ }^{7}$ Molecular Entomology and Vector Control Research Laboratory, Nigerian Institute of Medical Research, Lagos, Nigeria. ${ }^{8}$ Agricultural Research Station (Pty) Ltd., Friedenhiem JT 282, Nelspruit, South Africa. ${ }^{9}$ Vestergaard Frandsen Laboratories, 253/9 Minh Khai, Hai Ba Trung district, Hanoi, Vietnam.

Published: 15 October 2012

\section{References}

1. Burns M, Rowland M, N'Guessan R, Carneiro I, Beeche A, Sesler Ruiz S, Kamara S, Takken W, Carnevale R, Allan R: Insecticide treated plastic sheeting for emergency malaria prevention and shelter amongst displaced population: an observational cohort study in a refugee setting in Sierra Leone. Am J Trop Med Hyg 2012, 87:242-250.

2. Chandre F, Dabire RK, Hougard JM, Djogbenou L, Irish SR, Rowland M, N'Guessan R: Field efficacy of pyrethroid treated plastic sheeting (durable lining) in combination with long lasting insecticidal nets against malaria vectors. Parasit Vectors 2010, 3:65

3. Diabate A, Chandre F, Rowland M, N'Guessan R, Duchon S, Dabire KR, Hougard JM: The indoor use of plastic sheeting pre-impregnated with insecticide for control of malaria vectors. Trop Med Int Health 2006, 11:597-603.

4. Messenger LA, Miller NR, Adeogun AO, Awolola TS, Rowland M: The development of insecticide-treated durable wall lining for malaria control: insights from rural and urban populations in Angola and Nigeria. Malaria J 2012, Accepted.

doi:10.1186/1475-2875-11-S1-P121

Cite this article as: Messenger et al: Insecticide-treated durable wall lining for malaria control: multicentre studies from Africa and SouthEast Asia. Malaria Journal 2012 11(Suppl 1):P121.

\section{Submit your next manuscript to BioMed Central and take full advantage of:}

- Convenient online submission

- Thorough peer review

- No space constraints or color figure charges

- Immediate publication on acceptance

- Inclusion in PubMed, CAS, Scopus and Google Scholar

- Research which is freely available for redistribution

Submit your manuscript at www.biomedcentral.com/submit
Biomed Central 